\title{
Physiological hypertrophy of the heart and atrial natriuretic peptide during rest and exercise
}

\author{
JENS SVANEGAARD, * KRISTIAN ANGELO-NIELSEN, JAN SCHULTZ HANSEN \\ From the Department of ${ }^{\star C l i n i c a l ~ C h e m i s t r y ~ a n d ~ t h e ~ D e p a r t m e n t ~ o f ~ C a r d i o l o g y ~ a n d ~ I n t e r n a l ~ M e d i c i n e, ~}$ \\ Svendborg Hospital, Svendborg, Denmark
}

SUMMARY The influence of physiological cardiac hypertrophy on the concentration of plasma atrial natriuretic peptide was studied in six male athletes and six normally active, matched control men. They were examined by echocardiography during a graded exercise test on a bicycle ergometer. Plasma atrial natriuretic peptide was measured at rest, at each workload until exhaustion, and 15 and 30 minutes after the exercise test. Echocardiography showed that the athletes had a significantly larger left atrium, left ventricular end diastolic diameter, left ventricular posterior wall, interventricular septum, left ventricular ejection fraction, and left ventricular mass than the controls. The athletes performed significantly more work than the control group- $325 \mathrm{~W}$ $v 277 \mathrm{~W}$. The plasma concentration of atrial natriuretic peptide rose by a mean factor of $2 \cdot 76$ (range $1 \cdot 78-4 \cdot 28$ ) in all men from rest to maximum exercise. There were no differences between the athletes and the controls in the concentrations of plasma atrial natriuretic peptide at rest, at any workload, or at maximum workload. Neither was there any difference in the increase in plasma atrial natriuretic peptide between the groups. There was no correlation between the plasma concentrations of atrial natriuretic peptide and any of the variables measured by echocardiography.

In healthy young men plasma atrial natriuretic peptide rises by a factor of about 2.8 during maximum exercise and the size of the chambers on the left side of the heart or left ventricular hypertrophy does not seem to influence the concentration of plasma atrial natriuretic peptide at rest or during exercise.

Atrial natriuretic peptide is a circulating hormone secreted by the atrial myocytes of the heart. It is released in response to increased atrial pressure, ${ }^{1}$ which is generally equal to increased stretch and dilatation of the atrial wall. Plasma atrial natriuretic peptide rose during exercise. ${ }^{2}$

The term "athelete's heart" was introduced by Henschen in $1899 .^{3}$ In this condition all the chambers of the heart are dilated and there is hypertrophy of the myocardium due to physical training. ${ }^{45}$

The purpose of this study was to determine whether the hypertrophy and dilatation of the heart seen in well trained persons influence the plasma concentration of atrial natriuretic peptide at rest or during exercise.

Requests for reprints to Dr Jens Svanegaard, Department of Cardiology, Odense University Hospital, Odense C, Denmark DK5000.

Accepted for publication 27 June 1989

\section{Patients and methods}

We studied six male footballers who trained strenuously and six normally active healthy matched controls (aged 21-30 years). None was taking medical treatment. The controls did not participate in any form of athletics for more than four hours a week. They all gave informed consent and the study was approved by the local ethics committee.

All of the investigations were undertaken between $3 \mathrm{pm}$ and $7 \mathrm{pm}$. Echocardiography, with cross sectional and $M$ mode recordings, was performed with a Hewlett Packard 77020A ultrasonograph and a $3.5 \mathrm{MHz}$ transducer on men in the supine position. All the $\mathrm{M}$ mode measurements originated from three or four consecutive cardiac cycles graded according to the system of the American Society of Echocardiography. ${ }^{6}$ Calculations of the left ventricular ejection fraction and the left ventricular mass were based on the assumption that the left ventricle is ellipsoid. ${ }^{7}$ We took Henry et al's data as normal values, ${ }^{8}$ except 
for the calculation of the left ventricular mass, where we used the formula: left ventricular mass $=43.62+2.18 \times$ weight $(\mathrm{kg})$. The upper normal limit was +2 standard deviations (that is the left ventricular mass plus $30 \%$ ). ${ }^{9}$

The men had fasted for two hours before the exercise test and a cannula was inserted in an antecubital vein 30 minutes before the test. An electrocardiogram and auscultation of the heart were obtained before the test.

The subjects sat on the bicycle ergometer after a 30 minute rest in the supine position then blood pressure and pulse rate were measured. Graded exercise was performed by increasing the workload by $60 \mathrm{~W}$ every three minutes, starting at $120 \mathrm{~W}$ and continuing until exhaustion. Blood pressure and pulse rate were measured and a blood sample was drawn during the last 60 seconds of each work period and at 15 and 30 minutes after maximum exercise with the subject resting on the bicycle or a chair. Blood pressure was measured by the standard cuff technique.

Samples were collected in tubes coated in edetic acid and containing aprotinin $(500 \mathrm{IU} / \mathrm{ml}$ blood $)$ and kept in an ice bath. After centrifugation for 15 minutes at $7000 \mathrm{rpm}$ at $4^{\circ} \mathrm{C}$, the plasma was stored at minus $20^{\circ} \mathrm{C}$. Concentrations of plasma atrial natriuretic peptide were measured by a kit from INC $\bar{c}$

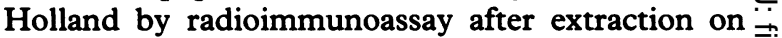
Sep-Pak C-18 cartridges. ${ }^{10}$ We have tested the kit in $\stackrel{5}{9}$ our laboratory: intra-assay and interassay variation 0 did not exceed $5 \%$ and $10 \%$, respectively, within the 흘 useful range $\left(B=15-85 \%\right.$ of $B_{0}$ where $B$ is the count $\frac{\bar{c}}{\frac{D}{\sigma}}$ for the standard (or sample) and $B_{0}$ is the count for $\stackrel{\Phi}{\propto}$ the standard without atrial natriuretic peptide). \& Recovery of added atrial natriuretic peptide was $99 \%$. Sensitivity was $0.8 \mathrm{pg} /$ tube $(4 \mathrm{pg} / \mathrm{ml}(1.3$. pmol/1) plasma).

Statistical analysis was performed by Student's $t \stackrel{\omega}{\circ}$ test for paired and unpaired data. The dependence of the plasma concentration of atrial natriuretic peptide on the amount of work was examined by analysis of $\stackrel{N}{\sigma}$ variance on the logarithm of the plasma concentra- $A$ tion of atrial natriuretic peptide (figure). A p value or $<0.05$ was considered to be significant.

\section{Results}

Age, weight, and body surface area were similar in the trained and the untrained groups.

Table 1 shows echocardiographic results. The left $\vec{\theta}$ ventricular mass was bigger in the athletes o $(p<0.0001)$. Each athlete had a calculated left

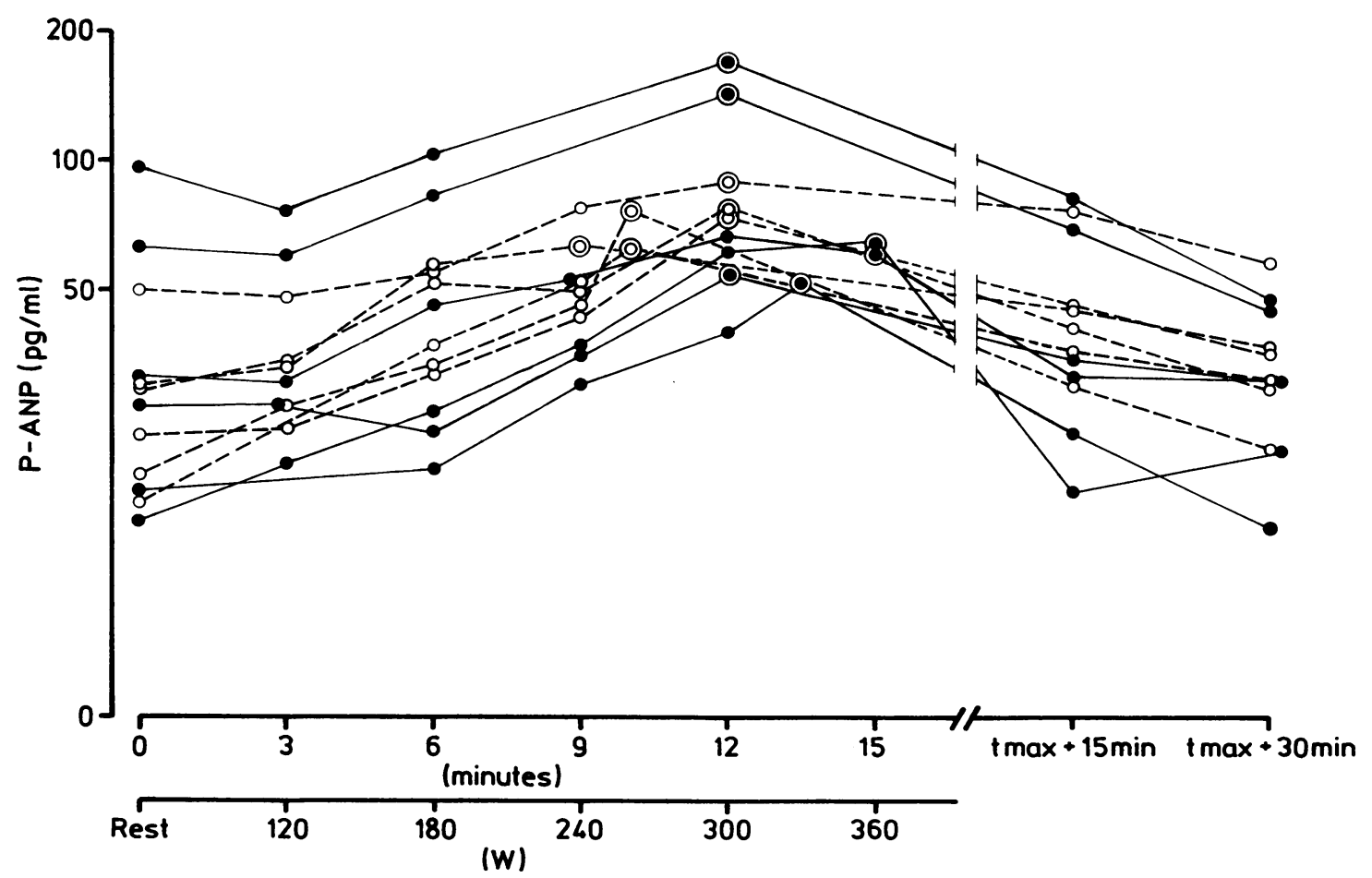

Figure Response of plasma concentration of atrial natriuretic peptide (on a logarithmic scale) to graded exercise on a bicycle ergometer. Closed circles, athletes; open circles, untrained controls; double circles, maximum exercise. 1 pg/ml of atrial natriuretic peptide $=0.325$ pmol $/$ l. 
Table 1 Measurements in athletes and controls (mean (SD))

\begin{tabular}{|c|c|c|c|}
\hline & $\begin{array}{l}\text { Athletes } \\
(n=6)\end{array}$ & $\begin{array}{l}\text { Controls } \\
(n=6)\end{array}$ & $p$ \\
\hline $\begin{array}{l}\text { Age (yr) } \\
\text { Height }(\mathrm{cm}) \\
\text { Weight (kg) } \\
\text { Body surface area }\left(\mathbf{m}^{2}\right) \\
\text { Pulse rate: }\end{array}$ & $\begin{array}{l}25 \cdot 8(2 \cdot 3) \\
182(7 \cdot 4) \\
75 \cdot 7(8 \cdot 7) \\
1.97(0 \cdot 15)\end{array}$ & $\begin{array}{c}24 \cdot 2(4 \cdot 2) \\
182(3 \cdot 8) \\
73 \cdot 5(7 \cdot 3) \\
1.94(0 \cdot 11)\end{array}$ & $\begin{array}{l}0.4 \\
0.9 \\
0.7 \\
0.7\end{array}$ \\
\hline $\begin{array}{l}\text { At rest } \\
\text { At maximal work } \\
\mathrm{BP}(\mathrm{s}) \text { : }\end{array}$ & $\begin{array}{c}60.3(0.8) \\
187(13.7)\end{array}$ & $\begin{array}{l}95 \cdot 0(18 \cdot 7) \\
192(7 \cdot 5)\end{array}$ & $\begin{array}{l}0.001 \\
0.5\end{array}$ \\
\hline $\begin{array}{l}\text { At rest (mm } \mathbf{H g}) \\
\text { At max work (mm } \mathbf{~ H g}) \\
\text { Maximal work (W) } \\
\text { Left atrium (mm) } \\
\text { LV ESD (mm) } \\
\text { LV EDD (mm) } \\
\text { Interventricular septum (mm) } \\
\text { LV posterior wall (mm) } \\
\text { LV fractional shortening (\%) } \\
\text { LV ejection fraction }(\%) \\
\text { LV mass (g) }\end{array}$ & $\begin{array}{l}121(11) \\
195(14) \\
325(30) \\
35 \cdot 2(1 \cdot 7) \\
34 \cdot 8(3 \cdot 3) \\
55 \cdot 8(4 \cdot 9) \\
10 \cdot 3(1 \cdot 2) \\
11 \cdot 0(0 \cdot 9) \\
37 \cdot 7(3 \cdot 7) \\
76 \cdot 8(3 \cdot 8) \\
299(28)\end{array}$ & $\begin{array}{l}118(10) \\
185(15) \\
277(27) \\
30 \cdot 7(4 \cdot 1) \\
33 \cdot 8(2 \cdot 0) \\
47 \cdot 7(2 \cdot 9) \\
8 \cdot 33(1 \cdot 0) \\
8 \cdot 67(0 \cdot 8) \\
29 \cdot 0(2 \cdot 5) \\
67 \cdot 1(3 \cdot 2) \\
170(15)\end{array}$ & $\begin{array}{l}0.7 \\
0.26 \\
0.01 \\
0.03 \\
0.5 \\
0.005 \\
0.01 \\
0.001 \\
0.001 \\
0.001 \\
<0.0001\end{array}$ \\
\hline
\end{tabular}

BP(s), systolic blood pressure; LV, left ventricular; ESD, end systolic diameter; EDD, end diastolic diameter.

ventricular mass that was above normal $(2 \cdot 11-$ 4.08 SD above normal mean), whereas all the controls had a left ventricular mass within the normal range ( $\pm 2 S D$ of normal mean). The diameters of the left atria did not exceed the normal range. The calculated left ventricular fractional shortening and ejection fraction were below the upper normal limits.

The athletes had a larger left atrium, a larger left ventricular end diastolic dimension, thicker interventricular septum and left ventricular posterior wall, and a greater left ventricular fractional shortening than the control group. The left ventricular end systolic dimension was similar in both groups.

The pulse rate at rest was higher in the nonathletes than in the athletes, probably because the non-athletes were more nervous before the exercise test. The blood pressure both before and during the exercise test was similar in the two groups. As expected the athletes reached a higher maximum workload.

Table 2 Plasma concentration of atrial natriuretic peptide at rest and at maximum work in athletes and non-athletes (mean $(S D)$ )

\begin{tabular}{|c|c|c|c|}
\hline$P-A N P$ & $\begin{array}{l}\text { Athletes } \\
(n=6)\end{array}$ & $\begin{array}{l}\text { Controls } \\
(n=6)\end{array}$ & $p$ \\
\hline $\begin{array}{l}\text { At rest }(\mathrm{pg} / \mathrm{ml}) \\
\text { At max work }(\mathrm{pg} / \mathrm{ml}) \\
\text { Increase }(\mathrm{pg} / \mathrm{ml})^{\star} \\
\text { Factor } \dagger\end{array}$ & $\begin{array}{c}41 \cdot 4(32 \cdot 1) \\
90 \cdot 6(52 \cdot 1) \\
49 \cdot 2(22 \cdot 4) \\
2 \cdot 57(0 \cdot 94)\end{array}$ & $\begin{array}{c}28.0(12 \cdot 1) \\
74.5(10 \cdot 1) \\
46.5(9 \cdot 13) \\
2.95(0.92)\end{array}$ & $\begin{array}{l}0.6 \\
0.5 \\
0.8 \\
0.5\end{array}$ \\
\hline
\end{tabular}

The figure shows the values of the plasma atrial natriuretic peptide on a logarithmic scale for the athletes and the controls before, during, and after exercise. Both the untrained and trained men had a significant rise in the concentration of atrial natriuretic peptide during exercise. There were no differences between the two groups in plasma concentrations of atrial natriuretic peptide at rest, at any workload, at maximal workload, or after the exercise. The factor by which the plasma atrial natriuretic peptide concentration rose during the exercise test was similar in both groups (table 2). Therefore the data were pooled in order to obtain plasma concentrations of atrial natriuretic peptide for all the healthy young men both at rest and at maximum workload (table 3).

There was no correlation between the plasma concentration of atrial natriuretic peptide at rest and any of the variables measured during echocardiography $(r \leqslant 0.36, p \geqslant 0.25)$. Despite the fact that atrial natriuretic peptide is produced in the atrial wall the correlation between plasma atrial natriuretic peptide and the diameter of the left atrium was only $0.21(p=0.5)$. Further, both the blood pressure and the pulse rate were correlated poorly with the plasma concentration of atrial natriuretic peptide.

\section{Discussion}

It is known that the heart is hypertrophic and dilated in well-trained athletes. ${ }^{45}$ In our male athletes we found a significantly increased diastolic cavity dimension, left ventricular posterior wall, interventricular septal thickness, left ventricular ejection fraction, and left ventricular mass compared with our untrained controls. These observations have been described earlier. ${ }^{112}$

We were unable to show any difference in the plasma concentration of atrial natriuretic peptide between the trained and the untrained group, even though the heart was significantly larger in the athletes than in the control subjects.

Physiological hypertrophy of the heart, as seen in athletes after a period of intensive training, does not seem to influence the plasma concentration of atrial

Table 3 Plasma concentrations of atrial natriuretic peptide $(P-A N P)$ at rest and maximal work in 12 healthy young men

\begin{tabular}{lccc}
\hline$P-A N P$ & Mean & SEM & Range \\
\hline At rest $(\mathrm{pg} / \mathrm{ml})$ & $34 \cdot 7$ & $6 \cdot 97$ & $14 \cdot 5-96 \cdot 5$ \\
At max work $(\mathrm{pg} / \mathrm{ml})$ & $82 \cdot 5$ & $10 \cdot 6$ & $51 \cdot 5-172$ \\
Increase $(\mathrm{pg} / \mathrm{ml})$ & $47 \cdot 8$ & $4 \cdot 73$ & $27 \cdot 5-78 \cdot 5$ \\
Factor & $2 \cdot 76$ & $0 \cdot 26$ & $1 \cdot 78-4 \cdot 28$ \\
\hline
\end{tabular}

See footnote to table 2 
natriuretic peptide or the release of atrial natriuretic peptide during exercise.

It is known that excretion of plasma atrial natriuretic peptide increases during exercise. ${ }^{213}$ Plasma atrial natriuretic peptide is controlled by stretch receptors in the left and right atria of the heart. The plasma concentrations of atrial natriuretic peptide during chronic or acute cardiac failure correlated with pulmonary capillary wedge pressure. ${ }^{1415}$ Because pulmonary capillary wedge pressure increases during exercise ${ }^{16}$ the rising concentrations of plasma atrial natriuretic peptide during exercise may be a response to the stretch that results from the increased pressure in the left atrium. The plasma concentrations of atrial natriuretic petide did not differ in the athletic and non-athletic groups in our study. This suggests that there was no difference in the left atrial pressure between the two groups either at rest or during exercise. As far as we know this has not been reported before.

Although the left atrium was larger in the athletes than in the controls, the correlation between this enlargement and plasma concentrations of atrial natriuretic peptide at rest was only minor and not statistically significant. A similarly poor correlation between the left atrium measured by echocardiography and the plasma concentration of atrial natriuretic peptide $(r=0.28, p>0.2)$ was described in 30 patients with various heart diseases or no heart disease at all, who were referred for routine echocardiography, ${ }^{17}$ whereas a good correlation ( $r=0.61, p<0.01)$ between the size of the left atrium and the plasma concentration of atrial natriuretic peptide was reported in 14 patients with various organic heart diseases. ${ }^{18}$ The plasma concentration of atrial natriuretic peptide may therefore reflect the size of the left atrium in the sick and failing heart, while the size of the left atrium is of little, if any, importance to the plasma concentration of atrial natriuretic peptide released by the healthy heart.

In patients with chronic heart failure, the heart works harder, and this will result in a hypertrophy of the heart. A production of atrial natriuretic peptide in this condition might be detected not only in the myocytes of the atria, but also in the ventricular myocytes. ${ }^{1920}$ The mechanisms responsible for the ventricular production are unknown. As in the atria, stretching of the muscle wall may trigger the production of the peptide by the ventricle. ${ }^{21}$ It has been suggested that the higher concentrations of the peptide in the failing ventricles may be the result of hypertrophy. Our results indicate that hypertrophy does not initiate a production of natriuretic peptide in the ventricles sufficiently to increase significantly the concentration of plasma atrial natriuretic peptide above that in normal people with non-hypertrophic hearts.

We conclude that plasma atrial natriuretic peptide increases by a factor of about $2 \cdot 8$ during maximum exercise in healthy young men. Neither the size of the chambers of the left side of the heart nor left ventricular hypertrophy seem to be important to the concentration of plasma atrial natriuretic peptide during rest and exercise.

This study was supported by grants from the medical research council of the county of Funen. Statistical support was obtained from the Danish Medical Research Council.

\section{References}

1 Lang RE, Thoelken H, Ganten D, Luft FC, Ruskoaho $\mathrm{H}$, Unger $\mathrm{Th}$. Atrial natriuretic factor-a circulating hormone stimulated by volume loading. Nature 1985;314:264-6.

2 Bollerslev J, Svanegaard J, Blaabjerg O, Pindborg T. Atrial natriuretic peptide in relation to physical exercise. Scand J Clin Lab Invest 1987;47:681-5.

3 Henschen HE. Eine medizinische Sportstudie. Skilauf und Skiwettlauf in Uppsala. Mitteilungen aus der medizinishen Klinik. Jena: Fischer, 1899.

4 Nishimura T, Yoshihasa Y, Kawai C. Echocardiographic evaluation of long-term effects of exercise on left ventricular hypertrophy and function in professional bicyclists. Circulation 1980;61:832-40.

5 Hauser AM, Dressendorfer RH, Vos M, Hashimoto T, Gordon S, Timmis GC. Symmetric cardiac enlargement in highly trained endurance athletes: a two dimensional echocardiographic study. Am Heart $J$ 1985;109:1038-44.

6 Sahn DJ, DeMaria A, Kisslo J, Weyman A. Recommendations regarding quantitation in $\mathrm{M}$-mode echocardiography: results of a survey of echocardiographic measurements. Circulation 1978;58 1072-83.

7 Troy BL, Pombo J, Rackley CE. Measurements of left ventricular wall thickness and mass by echocardiography. Circulation 1972;45:602-11.

8 Henry WL, Gardin JM, Ware JH. Echocardiographic measurements in normal subjects from infancy to old age. Circulation 1980;62:1054-61.

9 Savage DD, Abbott RD, Anderson SJ, Padgett S. Determinants of left ventricular mass and reference values based on a large population-based sample of apparently healthy subjects: the Framingham study [Abstract]. Circulation 1983;68(suppl 3):336.

10 Rosmalen FMA, Tan ACITL, Tan HS, Benraad TJ. A sensitive radioimmunoassay of atrial natriuretic peptide in human plasma, using a tracer with an immobilized glucouril agent. Clin Chim Acta 1987; 165:331-40.

11 Fagard R, Aubert A, Staessen J, Eynde EV, Vanhess L, Amery A. Cardiac structure and function in cyclists and runners. Comparative echocardiographic study. 
Br Heart $J$ 1984;52:124-9.

12 Shapiro LM. Physiological left ventricular hypertrophy. Br Heart J 1984;52:130-5.

13 Follenius $M$, Brandenburger $G$. Increase in atrial natriuretic peptide in response to physical exercise. Eur J Appl Physiol 1988;57:159-62.

14 Richards AM, Cleland JGF, Tonolo G, et al. Plasma alpha natriuretic peptide in cardiac impairment. $\mathrm{Br}$ Med J 1986;293:409-12.

15 Matsubara $H$, Nishikawa $M$, Umeda $Y$, et al. The role of atrial pressure in secreting atrial natriuretic polypeptides. Am Heart J 1987; 113:1457-63.

16 Yoshida A, Kadota K, Kambara H, et al. Left ventricular responses to supine exercise assessed by radionuclide angiocardiography and a Swan-Ganz catheter. Jpn Circ J 1985;49:661-71.

17 Crozier JG, Nicholls MG, Ikram H, Espiner EA.
Relation between left atrial diameter and plasma atrial natriuretic peptide. Am J Cardiol 1986;58:1134-6.

18 Haass $M$, Fischer TA, Dietz $R$. Is atrial distension the physiological stimulus for release of atrial natriuretic peptide? Lancet 1987;ii:1269-70.

19 Nemer M, Lavigne J-P, Drouin J. Ventricular atrial natriuretic factor gene expression: a marker for cardiac hypertrophy [Abstract]. J Cell Biochem 1988;suppl 12A:17.

20 Edwards BS, Ackermann DM, Lee ME, Reeder GS, Wold LE, Burnett JC Jr. Identification of atrial natriuretic factor within tissue in hamsters and humans with congestive heart failure. J Clin Invest 1988;81:82-6.

21 Galipeau J, Nemer M, Drouin J. Ventricular activation of atrial natriuretic factor gene in acute myocardial infarction. $N$ Eng $J$ Med 1988;319:654-5. 